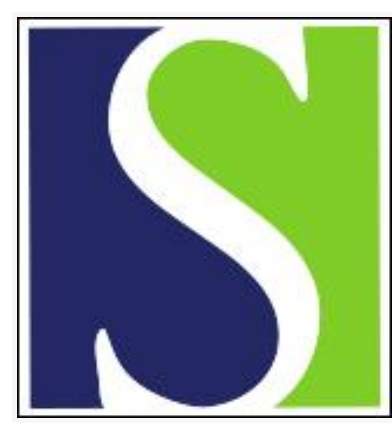

Scand J Work Environ Health 1992;18(4):252-256

https://doi.org/10.5271/sjweh.1581

Issue date: 01 Aug 1992

Lack of renal changes in stainless steel welders exposed to chromium and nickel.

by Vyskocil A, Smejkalova J, Tejral J, Emminger S, Vincentova M, Ettlerova E, Lauwerys R, Bernard A

Affiliation: Charles University, Hradec Kralove, Czechoslovakia.

This article in PubMed: www.ncbi.nlm.nih.gov/pubmed/1411368

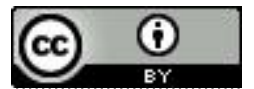




\title{
Lack of renal changes in stainless steel welders exposed to chromium and nickel
}

\author{
by Adolf Vyskocil, PhD, ${ }^{1}$ Jindra Smejkalova, ${ }^{1}$ Jaroslav Tejral, ${ }^{1}$ Stanislav Emminger, ${ }^{1}$ \\ Marie Vincentova, ${ }^{1}$ Eva Ettlerova, ${ }^{1}$ Robert Lauwerys, MD, ${ }^{2}$ Alfred Bernard, $\mathrm{PhD}^{2}$
}

\begin{abstract}
VYSKOCIL A, SMEJKALOVA J, TEJRAL J, EMMINGER S, VINCENTOVA M, ETTLEROVA E, LAUWERYS R, BERNARD A. Lack of renal changes in stainless steel welders exposed to chromium and nickel. Scand J Work Environ Health 1992;18:252-6. Biochemical markers of kidney damage were examined in 52 male stainless steel welders (manual metal arc welding) exposed to chromium and nickel. No difference was found in the mean urinary excretion of total proteins, albumin, protein 1, transferrin, retinol-binding protein, lactate dehydrogenase, lysozyme, or beta- $\mathrm{N}$-acetylglucosaminidase in a comparison with matched referents. Beta ${ }_{2}$-microglobulin was slightly increased in those welders with a urinary chromium concentration of $>64.5 \mathrm{nmol} \cdot \mathrm{mmol}^{-1}$ creatinine. The prevalences of abnormal values did not differ from those observed in the reference group. No correlation was found between the concentrations of chromium or nickel in urine and that of proteins or enzymes. No consistent or clinically significant renal impairment was revealed among the stainless steel welders exposed to a chromium air concentration slightly above the current threshold limit value of the American Conference of Governmental Industrial Hygienists for water-soluble hexavalent chromium compounds $\left(50 \mu \mathrm{g} \cdot \mathrm{m}^{-3}\right)$.
\end{abstract}

Key terms: chromium, enzymes, nephrotoxicity, nickel, proteins, welders.

Hexavalent (VI) chromium can produce acute renal tubular effects in humans or animals. Depending on the dose, these effects can vary from slight tubular proteinuria to acute tubular necrosis and renal failure. Other signs of tubular toxicity induced by chromium salts include enzymuria, aminoaciduria, and histuria (1).

The question of whether chronic exposure to soluble chromium compounds can induce nephrotoxic effects is still controversial. Epidemiologic studies carried out so far have not consistently suggested an adverse effect on renal function (2-10).

The present study was conducted on a group of stainless steel welders who had been exposed to chromium-containing fumes for 18 years on the average. These workers were also exposed to low concentrations of nickel, a metal which might also exert some effects on the kidney (11). A battery of sensitive markers of nephrotoxicity has been applied to these workers and their referents in order to determine whether long-term exposure to chromium or nickel in welding operations represents, as suggested by some studies $(2,4,7)$, a significant risk to renal function.

\footnotetext{
1 Charles University and Regional and District Hygiene Stations, Hradec Kralové, Czechoslovakia.

2 Unit of Industrial Toxicology and Occupational Medicine, School of Medicine, Catholic University of Louvain, Brussels, Belgium.
}

Reprint requests to: Dr A Bernard, Unit of Industrial Toxicology and Occupational Medicine, School of Medicine, Catholic University of Louvain, 30.54. Clos Chapelle-auxChamps, B-1200 Bruxelles, Belgium.

\section{Subjects and methods}

The group of exposed subjects consisted of stainless steel welders (all male) working in a machine producing factory. These welders carried out manual metal arc welding of chromium-nickel alloyed steel using coated electrodes (MMA/SS). Their work conditions had always remained identical. Fifty-one age-matched men performing only administrative tasks in the same plant were used as referents.

All of the participants were asked to answer a selfadministered questionnaire which provided information on occupational, demographic, and health history. Workers suffering from, or having suffered from, a renal or urological disease or any affection likely to compromise the renal function (eg, diabetes, gout) were excluded from the study.

The exposure at workplaces representative of the various activities was assessed from measurements of the airborne concentration of chromium and nickel with a personal sampler. The filter holder was placed inside the welder's face mask. The welding fumes were aspirated with a battery-operated pump at a flow rate of $1.5 \mathrm{l} \cdot \mathrm{min}^{-1}$ and collected on a cellulose nitroester membrane filter (Synpor 4, Ý $36 \mathrm{~mm}$, mean pore size $0.85 \mu \mathrm{m}$ ). The sampling intervals ranged from 3 to $4 \mathrm{~h}$. The filters were ashed with nitric acid and hydrogen peroxide and analyzed for their chromium and nickel content by atomic absorption spectrometry with a Varian AA-175 spectrometer (12).

For both the welders and the referents, the concentration of chromium and nickel was also measured in a spot urine specimen collected after the shift at the end of the workweek. The urinary chromium and 
nickel concentrations were determined by atomic absorption spectrometry with a Varian AA-30 spectrometer and a Perkin Elmer 5000 spectrometer, respectively. The accuracy of the chromium determination was ascertained by participation in the Interlaboratory Comparison Program of the Centre de Toxicologie du Québec (Centre Hospitalier de l'Université Laval, Québec G1V 4G2).

At the time of the study, the values obtained on nine urine samples with chromium concentrations between 50 and $500 \mathrm{nmol} \cdot 1^{-1}$ were on the average 100.7 (SD $8.6 \%$ of the target value. For both chromium and nickel our laboratory participates also in the definition of reference materials from Behringwerke AG Diagnostica (Marburg 1, PO BOX 1140, D-3550 Germany). The values of chromium obtained at the time of the present survey were on the average 113 and $98.6 \%$ of the target value for chromium and nickel, respectively.

For the enzyme and protein determination, four spot urine samples were obtained from each subject on the first and last day of a typical workweek, each time upon arrival and at the end of the shift. All of the samples were collected over phosphate buffer $\mathrm{pH} 7.4$ containing sodium azide as a preservative. They were stored at $4^{\circ} \mathrm{C}$ until the analysis. The concentrations of retinol-binding protein, protein 1 , and transferrin in urine were determined by an automated latex agglutination assay (13-15). The concentrations of beta $_{2}$-microglobulin and albumin were determined by the RIM test (UVVVR Prague, Czechoslovakia). Urinary creatinine was determined by the alkaline picrate method (Autoanalyser Technicon). The urinary activity of lysozyme and that of beta- $N$-acetylglucosaminidase were measured by the methods of Litwack (16) and
Tucker et al (17), respectively. Lactate dehydrogenase in urine was assayed by the UV-test (Sevac, Czechoslovakia). Total proteins were determined by the BIOLA Test (Lachema, Czechoslovakia). All of the urinary parameters were corrected for their creatinine content. The results of the analyses performed on urine samples with a creatinine concentration lower than $0.045 \mathrm{mmol} \cdot 1^{-1}\left(0.4 \mathrm{~g} \cdot 1^{-1}\right)$ were discarded.

The Kolmogorov-Smirnov test was used to ensure that the variables were normally distributed on an arithmetic or log scale. The homogeneity of variances was checked by the F-test. Student's t-test was used to compare arithmetic or geometric means. The comparison of prevalences of elevated values was performed with the $2 \times 2$ chi-square test (with Yates' correction) using as cutoff values the geometric means plus two geometric standard deviations of the results of the reference group. The level of significance was taken as $\mathrm{P}<0.05$.

\section{Results}

The characteristics of the welders and their referents are summarized in table 1. The groups were well matched with respect to age, smoking habits, alcohol, and analgesics consumption. None of the subjects reported a regular use of solvents at home.

The mean concentration of chromium in air was slightly above the threshold limit value (TLV) of the American Conference of Governmental Industrial Hygienists $\left(50 \mu \mathrm{g} \cdot \mathrm{m}^{-3}\right.$ for water-soluble chromium VI compounds), whereas that for nickel was around $50 \%$ of the TLV $\left(50 \mu \mathrm{g} \cdot \mathrm{m}^{-3}\right.$ for nickel-soluble compounds). Fifty percent of the individual values of chromium in air exceeded the TLV. The welders' mean uri-

Table 1. Characteristics of the reference and exposed groups.

\begin{tabular}{|c|c|c|c|c|c|c|c|c|c|c|}
\hline \multirow[b]{2}{*}{ Characteristic } & \multicolumn{5}{|c|}{ Reference group } & \multicolumn{5}{|c|}{ Exposed group } \\
\hline & $N$ & $\begin{array}{l}\text { Arith- } \\
\text { metic } \\
\text { mean }\end{array}$ & SD & $\begin{array}{c}\text { Geo- } \\
\text { metric } \\
\text { mean }\end{array}$ & Range & $\mathbf{N}$ & $\begin{array}{l}\text { Arith- } \\
\text { metic } \\
\text { mean }\end{array}$ & $\mathrm{SD}$ & $\begin{array}{l}\text { Geo- } \\
\text { metric } \\
\text { mean }\end{array}$ & Range \\
\hline Number & 51 & $\cdot$ & $\cdot$ & $\cdot$ & $\cdot$ & 52 & $\cdot$ & $\cdot$ & $\cdot$ & $\cdot$ \\
\hline Age (years) & $\cdot$ & 40 & 10 & . & . & $\cdot$ & 43 & 9 & - & $\cdot$ \\
\hline Smokers & 30 & $\cdot$ & $\cdot$ & · & $\cdot$ & 31 & $\cdot$ & $\cdot$ & . & $\cdot$ \\
\hline Regular alcohol consumption ${ }^{a}$ & 6 & - & . & . & - & 5 & . & · & . & . \\
\hline Regular analgesics consumption ${ }^{b}$ & 4 & . & . & $\cdot$ & $\cdot$ & 6 & $\cdot$ & . & $\cdot$ & $\cdot$ \\
\hline Duration of employment (year) & $\cdot$ & · & $\cdot$ & 22 & $5-37$ & · & $\cdot$ & $\cdot$ & 25 & $8-38$ \\
\hline Duration of exposure (year) & . & $\cdot$ & $\cdot$ & - & $\cdot$ & . & . & $\cdot$ & 18 & $5-38$ \\
\hline Chromium in air $\left(\mu \mathrm{g} \cdot \mathrm{m}^{-3}\right)^{\mathrm{c}}$ & - & . & · & - & $\cdot$ & $\cdot$ & . & $\cdot$ & 64 & $7-161$ \\
\hline Nickel in air $\left(\mu \mathrm{g} \cdot \mathrm{m}^{-3}\right)^{\mathrm{c}}$ & . & . & . & - & . & . & . & . & 28 & $3-70$ \\
\hline $\begin{array}{l}\text { Chromium in urine } \\
\text { (nmol } \cdot \mathrm{mmol}^{-1} \text { creatinine) }\end{array}$ & $\cdot$ & $\cdot$ & $\cdot$ & 2.4 & $0.54-12.5$ & $\cdot$ & $\cdot$ & $\cdot$ & 38.7 & $4.3-1.68^{d}$ \\
\hline $\begin{array}{l}\text { Nickel in urine } \\
\left(\mathrm{nmol} \cdot \mathrm{mmol}^{-1} \text { creatinine }\right)\end{array}$ & . & . & . & 4.4 & $0.95-30.8$ & . & . & . & 8.7 & $2.5-36.1^{d}$ \\
\hline
\end{tabular}

a Number of subjects drinking more than five glasses of wine, beer, or liquor per week.

b Number of subjects consuming more than one tablet per week.

c Determined for 10 welders at the five most representative workplaces.

d Significantly different from the referents. 
Table 2. Urinary excretion of proteins and enzymes in workers exposed to chromium and nickel and in their referents.

\begin{tabular}{|c|c|c|c|c|c|c|c|c|}
\hline & \multirow{2}{*}{\multicolumn{2}{|c|}{$\begin{array}{l}\text { Reference } \\
\text { group } \\
(\mathrm{N}=51)\end{array}$}} & \multicolumn{6}{|c|}{ Exposed group } \\
\hline & & & \multicolumn{2}{|c|}{$(\mathrm{N}=52)$} & \multicolumn{2}{|c|}{$\begin{array}{l}\text { End of last workday } \\
\qquad(\mathrm{N}=50)\end{array}$} & \multicolumn{2}{|c|}{$\begin{array}{l}\text { Urinary chromium } \\
>64.5 \mathrm{nmol} \cdot \mathrm{mmol}^{-1} \\
\text { creatinine } \\
(\mathrm{N}=9)\end{array}$} \\
\hline & $\begin{array}{l}\text { Arith- } \\
\text { metic } \\
\text { meana }\end{array}$ & Range & $\begin{array}{l}\text { Arith- } \\
\text { metic } \\
\text { meana }\end{array}$ & Range & $\begin{array}{l}\text { Geo- } \\
\text { metric } \\
\text { mean }\end{array}$ & Range & $\begin{array}{l}\text { Geo- } \\
\text { metric } \\
\text { mean }\end{array}$ & Range \\
\hline Total proteins (mg $\cdot \mathrm{mmol}^{-1}$ creatinine) & 12.7 & $4-36.3$ & 12 & $1.2-60$ & 12 & $1.2-67$ & 11.8 & $2.3-54$ \\
\hline Albumin (mg $\cdot \mathrm{mmol}^{-1}$ creatinine) & 0.78 & $0.15-3.2$ & 0.82 & $0.13-6.2$ & 0.79 & $0.1-10$ & 1.09 & $0.17-3.4$ \\
\hline $\begin{array}{l}\text { Beta }{ }_{2} \text {-microglobulin }\left(\mu \mathrm{g} \cdot \mathrm{mmol}^{-1}\right. \\
\text { creatinine) }\end{array}$ & 9.6 & $3-40.6$ & 10.3 & $2.6-49.1$ & 10.9 & $2.4-56$ & 16.6 & $9.3-45.4^{*}$ \\
\hline Protein-1 $\left(\mu \mathrm{g} \cdot \mathrm{mmol}^{-1}\right.$ creatinine) & 27.7 & $1.04-209$ & 29.9 & $3.3-158$ & 21.9 & $13.8-162$ & 28.6 & $2.9-162$ \\
\hline Transferrin (mg $\cdot \mathrm{mmol}^{-1}$ creatinine) & 40.5 & $8.9-192$ & 47 & $8.1-868$ & 46.3 & $4.6-452$ & 68.8 & $15.5-280$ \\
\hline $\begin{array}{l}\text { Retinol-binding protein } \\
\left(\mu \mathrm{g} \cdot \mathrm{mmol}^{-1} \text { creatinine }\right)\end{array}$ & 16.9 & $6.1-38.8$ & 17.3 & $6.0-35.5$ & 15.4 & $4.4-43.7$ & 17 & $11-23$ \\
\hline $\begin{array}{l}\text { Lactate dehydrogenase (UI } \cdot \mathrm{mmol}^{-1} \\
\text { creatinine) }\end{array}$ & 0.85 & $0.15-3.6$ & 0.95 & $0.16-2.7$ & 0.61 & $0.01-36$ & 0.76 & $0.01-2.9$ \\
\hline Lysozyme ( $\mu \mathrm{g} \cdot \mathrm{mmol}^{-1}$ creatinine) & 26.5 & $1.2-179$ & 21.9 & $2.3-92$ & 19.6 & $1.2-83$ & 30 & $0.02-56$ \\
\hline 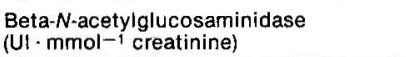 & 0.18 & $0.058-0.62$ & 0.21 & $0.1-0.67$ & 0.19 & $0.05-0.74$ & 0.21 & $0.09-0.47$ \\
\hline
\end{tabular}

a Mean of four measurements per subject.

* $P<0.05$, Student's t-test.

Table 3. Prevalences of elevated values ${ }^{a}$ of renal parameters.

\begin{tabular}{lccc}
\hline Urinary parameter & $\begin{array}{c}\text { Reference } \\
\text { group }^{\mathrm{b}} \\
(\%)\end{array}$ & $\begin{array}{c}\text { Exposed } \\
\text { group (\%) }\end{array}$ & $\begin{array}{c}\text { Exposed } \\
\text { group, end } \\
\text { of last } \\
\text { workday }\end{array}$ \\
\hline Albumin & 5.8 & 7.7 & $26^{*}$ \\
Beta -microglobulin & 7.8 & 3.8 & 12 \\
Protein-1 & 5.8 & 5.8 & 4 \\
Transferrin & 7.8 & 13.5 & 14 \\
Retinol-binding protein & 5.8 & 5.8 & 6 \\
Lactate dehydrogenase & 5.8 & 7.7 & 6 \\
Lysozyme & 5.8 & 0 & 0 \\
Beta-N-acetylglucosaminidase & 3.9 & 5.8 & 14 \\
\hline Total proteins & 7.8 & 7.7 & 12 \\
\hline
\end{tabular}

a Higher than the geometric mean +2 geometric SD of the reference

values. measurements.

* $P<0.05$, chi-square test with Yates' correction.

nary concentrations of chromium and nickel were respectively 10 and 2 times above that of the referents (table 1). The urinary excretion of proteins and enzymes in the referents and exposed subjects is compared in table 2 . For that comparison, the arithmetic mean of the four urinary analyses performed on each subject was calculated. No statistically significant difference was found in the urinary excretion of total proteins, albumin, beta ${ }_{2}$-microglobulin, protein 1 , transferrin, retinol-binding protein, lactate dehydrogenase, lysozyme, and beta- $N$-acetylglucosaminidase.

All of these parameters were also compared in the samples collected upon arrival at work or at the end of the workshift, on both the first and last day of the week. No statistically significant difference emerged from these separate comparisons (results not shown except those at the end of the last workday, which are presented in table 2).

Table 2 also shows the values of the renal parameters in the group of exposed workers with a urinary excre- tion of chromium higher than $64.5 \mathrm{nmol} \cdot \mathrm{mmol}^{-1}$ creatinine. The only marker to show a statistically significant difference was beta $a_{2}$-microglobulin. The concentrations of urinary albumin and transferrin were also slightly higher, but the differences from the values of the reference group did not reach the level of statistical significance.

Table 3 presents the results of the same parameters in terms of the prevalences of increased values (as defined in the Subjects and Methods section). A statistical difference was found only for albuminuria at the end of the last workday. We did not find any significant correlation between the urinary concentrations of chromium or nickel and that of the biochemical parameters.

\section{Discussion}

The manual metal arc welding of stainless steel carried out by these workers is the welding technique that generates the highest fume concentrations of soluble chromium (as high as $1000 \mu \mathrm{g} \cdot \mathrm{m}^{-3}$ ). Seventy to ninety percent of chromium in this type of weiding fume is present as soluble chromium VI $(18,19)$ (ie, in a form that can readily cross cellular membranes of the respiratory tract and other organs, particularly the kidney). Nickel, by contrast, is much less abundant in these fumes. This difference is reflected by the results of the air and biological monitoring. The average concentration of nickel in air was below the TLV and the urinary nickel values did not deviate much from what is usually considered the upper limit of normal (9.5 nmol $\cdot \mathrm{mmol}^{-1}$ creatinine) (20). Exposure to soluble chromium was more important since $50 \%$ of the individual air analyses exceeded the TLV and 
$17 \%$ of the urinary chromium values were above the tentative maximum permissible level of $64.5 \mathrm{nmol}$. $\mathrm{mmol}^{-1}$ creatinine (20).

The application of a battery of sensitive markers did not reveal any significant renal abnormality in these workers. No significant effect could be evidenced in the urinary excretion of albumin and transferrin, which are presently the most sensitive indices of glomerular barrier dysfunction. At the end of the last workday, the exposed workers showed a significantly higher prevalence of elevated albuminuria, but this effect was not corroborated by the assay of transferrin. The urinary excretion of enzymes and low-molecular weight proteins was also unchanged, indicating the absence of any subclinical tubular injury or dysfunction. A slight increase in beta $a_{2}$-microglobulinuria was observed in workers with a urinary chromium level higher than $64.5 \mathrm{nmol} \cdot \mathrm{mmol}^{-1}$ creatinine, but it is unlikely that this effect resulted from significant proximal tubular impairment since the urinary excretion of other low-molecular weight proteins was normal.

In agreement with the present observations a few previous studies $(5,6,8,9)$ have also failed to evidence consistent renal effects in workers exposed to chromium. In particular, Saner et al (6) and Littorin et al (5) reported no increase in the urinary excretion of beta $\mathrm{a}_{2}$-microglobulin in workers with mean concentrations of chromium in urine of 12 and $13.1 \mathrm{nmol}$. $\mathrm{mmol}^{-1}$ creatinine, respectively. In fact, the beta ${ }_{2}-$ microglobulin excretion in these two studies was found to be decreased in the exposed workers. Verschoor et al (10) and Zschiesche et al (8) examined workers with a lower exposure to chromium (mean urinary chromium $<10.8 \mathrm{nmol} \cdot \mathrm{mmol}^{-1}$ creatinine) and also found no indication of a renal effect.

By contrast, on the basis of beta ${ }_{2}$-microglobulin excretion, Lindberg \& Vesterberg (4) have suggested that a slight proximal tubular dysfunction may occur in chromium-exposed workers. The effect reported by these authors was however of marginal statistical significance $(P=0.045)$ and even questionable since it was based on the application of one-tailed tests. These authors made the assumption that beta b $_{2}$-microglobulinuria can only be increased, which is contradicted by studies of Saner et al (6) and Littorin et al (5). The exposure levels were low (between 2 and $20 \mu \mathrm{g}$ chromium $\cdot \mathrm{m}^{-3}$ ), but nevertheless a dose-response relationship was observed between the concentration of chromium in air and the prevalence of elevated beta -microglobulin in urine.

In Italy Franchini, Mutti and their co-workers (2, $3,7,9)$ conducted a series of cross-sectional studies on workers exposed to chromium in welding or chrome-plating operations or during the production of chromate salts. They found some evidence of tubular dysfunction or damage on the basis of urinary excretion of total protein, beta-glucuronidase, retinolbinding protein and the antigen Brush border 50. They even found dose-effect or dose-response relationships between the urinary excretion of chromium and that of retinol-binding protein and of the antigen Brush border 50 (9). Most of the abnormal values were observed in subjects with a urinary excretion of chromium higher than $32.3 \mathrm{nmol} \cdot \mathrm{mmol}^{-1}$ creatinine (ie, 15 $\mu \mathrm{g} \cdot \mathrm{g}^{-1}$ creatinine), but above that threshold the degree of tubular impairment was no longer related to the urinary excretion of chromium. Franchini \& Mutti (9) explained this phenomenon by postulating that tubular damage observed in chromium-exposed workers is transient and due mainly to acute exposures and that workers become progressively resistant to the effects of more severe or prolonged exposure. However, the failure in the present study to demonstrate any significant renal effects in workers excreting, on the average, $38.7 \mathrm{nmol}$ chromium $\cdot \mathrm{mmol}^{-1}$ creatinine and with a mean duration of exposure of 18 years indicates that, if soluble chromium VI compounds can produce renal changes in occupationally exposed subjects, it is unlikely that these effects occur in workers excreting less than $64.5 \mathrm{nmol}$ chromium $\cdot \mathrm{mmol}^{-1}$ creatinine (ie, $30 \mu \mathrm{g} \cdot \mathrm{g}^{-1}$ creatinine), which corresponds to the current $T L V$ of hexavalent chromium in air (20).

\section{Acknowledgments}

This study was financially supported by the Belgian State (Prime Minister's Service-Science Policy Office). The authors acknowledge also the financial support received from the European Science Foundation and Medical Research Councils. A Bernard is Maître de recherches du Fonds National Belge de la Recherche Scientifique.

The authors acknowledge the expert assistance of Dr J Kokes, Ms M Cizkova, Ms B Petrovicka, Ms H Markova, and Mr X Dumont.

\section{References}

1. International Programme on Chemical Safety, World Health Organization (WHO). Chromium: environ. Geneva: WHO, 1988. (Health criteria; no 61.)

2. Franchini I, Mutti A, Cavatorta A, Corradi A, Cosi A, Olivetti G, et al. Nephrotoxicity of chromium. Contrib Nephrol 1978;10:98-110.

3. Mutti A, Cavatorta A, Pedroni C, Borghi A, Giaroli $\mathrm{C}$, Franchini I. The role of chromium accumulation in the relationship between airborne and urinary chromium in welders. Int Arch Occup Environ Health 1979;43: $123-33$.

4. Lindberg $E$, Vesterberg $O$. Urinary excretion of proteins in chromeplaters, exchromeplaters and referents. Scand J Work Environ Health 1983;9:505-10.

5. Littorin M, Welinder $\mathrm{H}$, Hultberg B. Kidney function in stainless steel welders. Int Arch Occup Environ Health 1984;53:279-82.

6. Saner G, Yuzbasiyan V, Cigdem S. Hair chromium and excretion in tannery workers. Br J Ind Med 1984;41: $263-6$.

7. Mutti A, Lucertini S, Valcavi P, Neri TM, Fornari M, Alinovi R, Franchini I. Urinary excretion of brush border antigen revealed by monoclonal antibody: an early indicator of toxic nephropathy. Lancet 1985;2:914-6. 
8. Zschiesche W, Emmerling G, Schaller KH, Weltle D. Investigations on renal impairments of high alloy steel welders. In: Foa V, Emmett EA, Maroni M, Colombi A, ed. Occupational and environmental chemical hazards: cellular and biochemical indices for monitoring toxicity. Chichester: Ellis Horwood Limited Publishers, 1987:339-43.

9. Franchini I, Mutti A. Selected toxicological aspects of chromium (VI) compounds. Sci Total Environ 1988;71: 379-87.

10. Verschoor MA, Bragt PC, Herber RFM, Zielhuis RL, Zwennis WCM. Renal function of chrome-plating workers and welders. Int Arch Occup Environ Health 1988; 60:67-70.

11. Sunderman HW Jr, Horak E. Biochemical indices of nephrotoxicity exemplified by studies of nickel nephropathy. In: Brown SS, Davies DS, ed. Organdirected toxicity: chemical indices and mechanisms. Oxford: Pergamon Press, 1981:55-67.

12. Lo FB, Arai DK. Determination by atomic spectrometry of chromium of air sampling filters in the presence of iron. Am Ind Hyg Assoc J 1988;49:207-12.

13. Bernard AM, Lauwerys RR. Continuous flow-system for automation of latex immunoassay by particle counting. Clin Chem 1983;29:1007-11.

14. Bernard A, Lauwerys R, Noel A, Vandeleene B, Lambert A. Urine protein 1: a sex dependent marker of tubu- lar or glomerular dysfunction. Clin Chem 1989;35: $2141-2$.

15. Bernard A, Ouled Amor A, Goemare-Vanneste J, Antoine JL, Lauwerys RR, Lambert A, et al. Microtransferrinuria: a more sensitive indicator of early glomerular damage in diabetes than microalbuminuria. Clin Chem 1988;34:1220-1.

16. Litwack G. Photometric determination of lysozyme activity. Proc Soc Exp Biol Med 1955;39:401-3.

17. Tucker SM, Boyd PJR, Thompson AE, Price RG. Automated assay of $\mathrm{N}$-acetyl- $\beta$-glucosaminidase in normal and pathological urine. Clin Chim Acta 1975;62: $333-9$.

18. Stern RM. A chemical, physical and biological assay of welding fume. In: Brown RC, Gormley JP, Chamberlin M, Davis R, ed. The in vitro effects of mineral dusts. London: Academic Press 1980:203-9.

19. Kobayashi M, Tsutsumi S. Investigation on crystalline materials in welding fumes of covered electrodes. In: Stern RM, Berlin A, Fletcher AC, Järvisalo J, ed. Health hazards and biological effects of welding fumes and gases. Amsterdam: Excerpta Medica, 1986:77-80.

20. Lauwerys R. Industrial chemical exposure guidelines for biological monitoring. Davis, CA: Biomedical Publications, 1983 .

Received for publication: 17 May 1991 